\title{
EGR2 Gene
}

National Cancer Institute

\section{Source}

National Cancer Institute. EGR2 Gene. NCI Thesaurus. Code C131312.

This gene plays a role in both transcriptional regulation and protein sumoylation. 